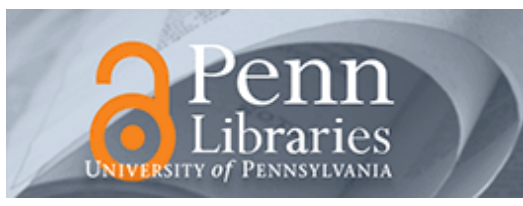

University of Pennsylvania ScholarlyCommons

Wharton Pension Research Council Working Papers

Wharton Pension Research Council

$11-1-2003$

\title{
Crime and Early Retirement Among Older Americans
}

Dan Silverman

University of Michigan, dansilv@umich.edu

Olivia S. Mitchell

The Wharton School, University of Pennsylvania, mitchelo@wharton.upenn.edu

Follow this and additional works at: https://repository.upenn.edu/prc_papers

Part of the Economics Commons

Silverman, Dan and Mitchell, Olivia S., "Crime and Early Retirement Among Older Americans" (2003). Wharton Pension Research Council Working Papers. 412.

https://repository.upenn.edu/prc_papers/412

This paper is posted at ScholarlyCommons. https://repository.upenn.edu/prc_papers/412

For more information, please contact repository@pobox.upenn.edu. 


\title{
Crime and Early Retirement Among Older Americans
}

\begin{abstract}
This paper investigates the relationship between local crime rates and the retirement decisions of older Americans. We do so by linking data from the Health and Retirement Study with measures of local crime patterns taken from the Federal Bureau of Investigation's Unified Crime Reports. If we condition on crime rates alone, there is either a weakly positive or no relationship between local crime patterns and older men's propensity to retire early. But unobservable factors associated with early retirement may be correlated with residence in higher-crime rate cities, so next we condition on both the expectation for the crime rate and deviations from average crime levels. We find a positive and statistically significant association between early retirement and expectations for murder rates, and a positive but, on average, imprecisely estimated positive association between early retirement and unexpected increases in crime. The effect of unanticipated increases in crime is greatest, and significant for those in poor health. In this latter group, men are 14 percent more likely to retire early given a standard deviation increase in unexpected murder rates. These findings are consistent with a pattern of more early retirement among those who live in higher crime areas, and earlier retirement among those in poor health when crime levels rise above anticipated levels.
\end{abstract}

\section{Disciplines}

Economics 


\title{
Crime and Early Retirement Among Older Americans
}

\author{
Dan Silverman and Olivia S. Mitchell
}

\section{Working Paper}

2004-1

\section{Boettner Center for Pensions and Retirement Research}

The Wharton School, University of Pennsylvania 3641 Locust Walk, 304 CPC

Philadelphia, PA 19104-6218

Tel: 215.898.7620 • Fax: 215.898.0310• Email: prc@wharton.upenn.edu http://rider.wharton.upenn.edu/ prc/Boettner.html

Boettner Center for Pensions and Retirement Research Working Papers are intended to make research findings available to other researchers in preliminary form, to encourage discussion and suggestions for revision before final publication. Opinions are solely those of the authors.

(C2004 Boettner Center for Pensions and Retirement Research of the Wharton School of the University of Pennsylvania. All Rights Reserved. 


\title{
Crime and Early Retirement Among Older Americans ${ }^{*}$ \\ Dan Silverman and Olivia S. Mitchell
}

November 2003

\begin{abstract}
This paper investigates the relationship between local crime rates and the retirement decisions of older Americans. We do so by linking data from the Health and Retirement Study with measures of local crime patterns taken from the Federal Bureau of Investigation's Unified Crime Reports. If we condition on crime rates alone, there is either a weakly positive or no relationship between local crime patterns and older men's propensity to retire early. But unobservable factors associated with early retirement may be correlated with residence in higher-crime rate cities, so next we condition on both the expectation for the crime rate and deviations from average crime levels. We find a positive and statistically significant association between early retirement and expectations for murder rates, and a positive but, on average, imprecisely estimated positive association between early retirement and unexpected increases in crime. The effect of unanticipated increases in crime is greatest, and significant for those in poor health. In this latter group, men are 14 percent more likely to retire early given a standard deviation increase in unexpected murder rates. These findings are consistent with a pattern of more early retirement among those who live in higher crime areas, and earlier retirement among those in poor health when crime levels rise above anticipated levels.
\end{abstract}

Dan Silverman (corresponding author)

Department of Economics, University of Michigan

611 Tappan Street, Ann Arbor, MI 48109.

Tel. (734) 327-2813

dansilv@umich.edu

Olivia S. Mitchell

Wharton School, University of Pennsylvania

3641 Locust Walk, Philadelphia PA 19104-6218

Tel: (215) 898-0424.

mitchelo@wharton.upenn.edu

\footnotetext{
* This research was conducted with support from the National Institutes of Health - National Institute on Aging, Grant number AG12836, and the Penn Aging Research Center (PARC). We thank Mark Keintz and Beth Soldo of PARC, Cathy Liebowitz and Michael Nolte of the Michigan's Institute for Social Research, and Jan Olson of the U.S. Social Security Administration, for facilitating this research. We thank Sara LaLumia for excellent research assistance.
} 


\section{Crime and Early Retirement Among Older Americans}

Little is known about how local amenities and community attributes influence the labor market decisions of older Americans. In this paper, we explore the relationship between a particular aspect of community life - namely, local crime rates - and how these influence older people's work and retirement decisions.

One motivation for our work derives from the potential vulnerability to crime of older people with limited resources and living in disadvantaged communities. Older people tend to be especially fearful being victimized by crime (Brillon, 1987), although evidence suggests that, in fact, they are relatively less likely to be victimized than average. For instance, the rate of criminal victimization for people age 50+ is eight times lower than among young adults age 16-24 (Rennison, 1999).

Another motivation for analyzing the relationship between crime and retirement patterns is an interest in how work and retirement decisions could influence the communities in which older people live. While exposure to local crime can alter individuals' work decisions, their work patterns may also affect crime levels, especially in economically disadvantaged communities. For example, sociological studies of low-income areas suggest that older people who remain engaged in their communities tend to supervise neighborhood youth and act as important role models (Anderson, 1990, 1999). By playing such supervisory roles the "old heads" may, in turn, reduce crime in lowincome neighborhoods. Such evidence suggests that the interactions between crime and older persons' labor market attachment deserve additional investigation.

Our approach draws on prior studies in both economics and sociology. One strand of analysis, in labor economics, ${ }^{1}$ finds that factors influencing retirement include social security

\footnotetext{
${ }^{1}$ For a review see Lumsdaine and Mitchell (1999).
} 
benefits (Rust and Phelan, 1997), company pensions (Fields and Mitchell, 1984; Stock and Wise, 1990), and health status (Dwyer and Mitchell, 1998). A separate and growing economics literature explores the trade-offs between crime and legal market work for the would-be criminal (Becker, 1968; Grogger, 1998; Levitt, 1998). This second strand focuses on potential perpetrators of crime, but does not consider potential victims' reactions in much detail. Hamermesh (1999) does examine how violent crime influences younger people's decisions to work night rather than daytime shifts, but he does not consider the retirement decision. Finally, a third strand of research describes how crime influences residential location decisions (Cullen and Levitt, 1999; Sampson and Woodredge, 1986), but these studies, too, do not evaluate the links between work and neighborhood attributes including crime. To this topic we turn next.

\section{Model and Data}

A community attribute such as a high crime rate has theoretically conflicting effects on retirement outcomes. On the one hand, more crime could make staying home (leisure) relatively more attractive than employment, contributing to earlier retirement. Also, threats of bodily injury or property loss in high crime areas might make avoiding the street more attractive than venturing out to work. Fear of crime can also produce joblessness, if people relocate to safer locations. The negative effect of crime on work at older ages could also be stronger for those in relatively poor health, with lower wealth, and having fewer neighborhood and family resources on which to rely for safety. Working in the opposite direction is the fact that more local crime could make continued work relatively more attractive, since retirement activities such as gardening, shopping, and walking, would be less pleasant. In this case, crime reduces the relative value of leisure, making employment more attractive. Another potential channel for the effect of crime on retirement behavior is the negative influence of higher crime on property values and homeowner wealth. This "income" effect, should induce continued work and delay retirement. Since the theoretical direction 
of the net effect is ambiguous, an empirical analysis of the net impact of crime on retirement is required.

Our model of the relationship between retirement and crime rates posits that the worker making retirement plans takes as given his community and economic environment, including expectations about future conditions. His decision to retire early - prior to age 65 - is therefore a function of initial conditions, treated as a vector of socio-demographic characteristics including age, race, marital status, level of education, self-assessed health, wealth, and various aspects of the individual's community at baseline. Holding constant these factors, we estimate a logistic regression linking the propensity to retire early to variation in local crime rates. In addition we examine whether deviations from expectations also influence behavior, modeled as random disturbances conditional on initial conditions. $^{2}$

\section{Data Sources}

To analyze the links between retirement behavior and local crime, we generate an extract from the nationally representative Health and Retirement Study (HRS), which is a longitudinal survey of 9,825 older Americans first interviewed in 1992 when they were age 51-61. Respondents and their spouses were followed every two years thereafter, with the latest year used in the present analysis being the 2000 wave. The HRS is valuable because it reports detailed information on a range of work, health, income, and demographic topics. ${ }^{3}$ To the respondent files, we link information on local crime rates taken from the Uniform Crime Reporting Program of the US Federal Bureau of Investigation (FBI-UCR). These are standardized county-level crime statistics by

\footnotetext{
${ }^{2}$ Crime rates and wealth, or crime and education. may be correlated, but our model does not allow for correlation between initial conditions and idiosyncratic tastes for early retirement, except through expectations for future crime. Heterogeneity in preferences for early retirement is thus assumed orthogonal to initial conditions, including expectations for future crime.

${ }^{3}$ Because of the confidential nature of the administrative and geographic data, researchers may accesss them only under extremely restricted condtions; see $\underline{w w w}$.umich.edu/ hrswww for details.
} 
type of crime, aggregated from the reports of 17,000 local law enforcement authorities. ${ }^{4}$ We merge these crime reports into the HRS file using respondent 1992 county of residence, after normalizing crime incidence patterns with data on local population taken from the 1990 U.S. Census. A final data source is information on average housing prices by county, also from the 1990 Census, which helps control for other regional amenities. ${ }^{5}$

The period we study with the HRS spans the five waves of available information, covering the ten years between 1992 and $2000 .^{6}$ In order to observe completed retirement transitions for our sample, we chose only workers age 56-61 in 1992 who reached at least age 65 by the time of their interview in $2000 .^{7}$ The empirical work is conducted separately for men and women, yet we focus mainly on older men since most were working at baseline so selection bias is unlikely to be serious. We further analyze only respondents for whom local crime data are available, for a final sample size of 2,257 observations. ${ }^{8}$

\section{Definitions of Retirement and Explanatory Variables}

We are interested in the relationship between local crime patterns and early retirement outcomes, yet there is no commonly agreed-on definition of retirement. For this reason, we consider two measures, the first of which designates a respondent an early retiree if he receives social security Old Age or DI benefits prior to age 65. The second measure we use defines early retirement as having work hours fall to zero before age 65 and remain at zero until age 65 .

\footnotetext{
${ }^{4}$ These reports cover 95 percent of the US population, including 96 percent of those living in Metropolitan Statistical Areas, and 92 percent of the population living in cities outside of metropolitan areas (FBI, 1999). It could be argued that perceived or experienced rather than reported crime rates may be preferred; indeed the U.S. Bureau of Justice Statistics (BJS) conducts an annual, nationally representative survey of individual crime victimization. Howe ver these data cannot be tabulated by geographic area to permit the calculation of experienced local crime rates.

${ }_{6}^{5}$ In future research we will link administrative data on social security and pension benefits.

${ }^{6}$ In this study we use five waves of the HRS currently available in public or preliminary release status; permission to link retirement outocomes with restriced data including geographic locators was obtained as required.

7 A respondent is defined as working if, at the time of the interview in 1992, he or she was "currently working for pay."

${ }^{8}$ The largest sample used in this paper consists of 1166 male and 1091 female respondents. An analysis of sample inclusion rules indicates that our sample is less likely to include younger respondents, Blacks, Hispanics, those with fewer years of schooling, those in poorer health, and those with lower earnings (see Table A1). Sample sizes also vary
} 
HRS workers are exposed to local crime of several different types, as reported in Table 1. Our sample of older workers lives in communities with somewhat higher rates of crime than the national average. For example, the national average murder rate is 0.96 per 10,000 residents, overall, but 1.02 per 10,000 residents for age-eligible HRS respondents, a small but statistically significant difference. If we restrict attention to residents of counties with at least 100,000 inhabitants, the average murder rate is even higher -- 1.15 per 10,000 residents among age-eligible HRS respondents - with the national average slightly lower, at 1.11 per 10,000 residents. HRS respondents in more populated counties also face somewhat higher assault and motor vehicle theft rates, as compared to average.

\section{Table 1 here}

Summary statistics for the male half of the sample appear in Table 2, with characteristics reported according to our two definitions of early retirement. Using either definition, the data show that male early retirees are somewhat less well educated and report themselves in poorer health than later retirees, though only the education differences are statistically significant. Early retirees also appear to have lower median financial assets, but there is no clear cross-group difference between earnings, household income, or net housing wealth. Early retirees do report that they live in communities with somewhat higher average crime rates and slightly higher average neighborhood quality, though measured differences are not always statistically significant. Median housing prices are lower in communities where early retirees live as compared to other workers using the benefitreceipt early retirement definition; the relationship is weaker for the hours-based early retirement definition. Similar patterns hold for women workers, but differences in means are small and not statistically significant (details available on request).

Table 2 here

due to uneveneness in the availabity of local crime measures. Murder rates are said to be reported more accurately by 
To evaluate the empirical links between early retirement and crime, we also include as explanatory variables two other indicators of community quality, namely local median housing prices, and respondent reports on neighborhood quality. Controlling for an area's median housing price should hold constant the average value of local amenities, to the extent that local amenities are capitalized in housing prices. In this way, we seek to identify how crime influences retirement behavior separately from its impact on the average value of all local amenities. To guard against the possibility that local amenities are imperfectly capitalized in housing prices, or that median housing prices are a noisy measure of the true local amenity levels because of systematic differences in average housing quality, we also control on an index of self-reported neighborhood quality measures ostensibly unrelated to crime. This index, derived from the HRS, summarizes respondents' answers to five questions about their neighborhoods and relationships with neighbors. Specifically, the questions inquire as to whether the respondent is generally satisfied with his neighborhood, whether he has relatives who live in the neighborhood, whether he has friends who live in the neighborhood, whether he knows most of his neighbors, and whether he is often social with neighbors. Means of this index across the various male samples are also reported in Table 2.

\section{Estimation Results: Crime Levels and Early Retirement}

Logistic parameters of the estimated effects of crime rates on men's propensity to take early retirement appear in Table 3. We focus mainly on the findings using murder rates and make note of other results only when the other crime measures produce different results. The murder rate is selected as local crime measure because there is reason to believe that murder is the best reported 
crime with least potential for measurement error. ${ }^{9}$ Subsequently we link the same crime measure to our other early retirement measure, a drop in work hours to zero. ${ }^{10}$

Table 3 here

Column (1) of Table 3 includes all HRS men for whom we have sufficient data on crime and other demographic and economic variables. ${ }^{11}$ These results indicate a positive relationship between the murder rate and men's propensity to retire early, a finding that is qualitatively robust to using other measures of crime. For example, replacing the murder rate with the assault rate (Table A2 Column 1) indicates a positive and statistically significant association between assault rates and the propensity for early retirement defined as early receipt of government benefits. ${ }^{12}$

Our alternative early retirement measure focuses on having hours worked fall to zero prior to age 65, and results appear in Table 4. Again Column (1) provides results for the murder rate, where we find the impact of local crime is negative but not statistically significant. A possible explanation for why results diverge depending on which retirement definition is used, is that positive work hours are permitted while receiving government retirement benefits. So respondents may have largely retired but not stopped work completely. Alternatively, the different results may be due to measurement error in hours worked. An HRS respondent might misremember the number of hours worked in the previous year, but it is less likely that he would either forget receiving government benefits or recall receiving a check if in fact he did not.

\footnotetext{
${ }^{9}$ The FBI-UCR data on crime are measured with error partly because of the level of aggregation at which the statistics are provided. Most studies of crime use the number of crimes per unit of population as the standard measure (Glaeser, et. al, 1996, Levitt, 1998), but the FBI-UCR's lowest level of aggregation is the county for most jurisdictions. This relatively high level of aggregation raises a question about possible intra-jurisdictional variation in crime rates. To gauge the influence of this error, we compare the estimated effect of the rate of crime per 10,000 residents to the estimated effect of the crime rate weighted by population density. The density-weighted crime rate is equivalent to the number of crimes in the county per square mile, which partly corrects for the fact that, regardless of intra-jurisdictional variation, exposure to a crime rate $R$ in a densely populated county is on average higher than exposure to the same crime rate in a sparsely populated county. Results from these specificiations are qualitatively similar to those using crime rates and are available on request.

${ }_{10}^{10}$ Parallel analyses for assault rates are provided in the Appendix.

${ }^{11}$ In this version of the analysis, pending approval to link geographic information with Social Security earnings and benefits files, wealth measures exclude social security wealth.
} 
Table 4 here

A parallel analysis for women may be found in Table 5. Here we note that the estimated relationships between local murder rates and women's propensity for early retirement are similar in sign, but imprecisely estimated. This pattern is similar across definitions of retirement specific crime measures employed.

Table 5 here

\section{Extended Analysis: Early Retirement and Residential Patterns}

The findings of the previous section suggest a positive association between local crime rates and men's propensity for early retirement. This positive relationship may derive from at least two sources which would be useful to disentangle. First, as discussed above, crime can have a causal effect on retirement decisions. From this perspective, our results could indicate that increases in crime rates cause earlier retirement. A second and equally plausible argument is that the estimated relationship between crime levels and retirement behavior reflects a correlation between early retirement and residential decisions. Such a correlation could arise if people preferring urban living might also be more likely to prefer earlier retirement. If this were the case, we would observe a positive correlation between crime levels and the propensity to retire early, even after conditioning on earnings, wealth, and other factors influencing retirement choices. Alternatively, unmeasured compensating differentials could exist in higher crime areas that make earlier retirement more desirable; for instance, people willing to work in higher crime areas could be rewarded with access to culture, recreation, and transportation, which is imperfectly captured by average housing prices or neighborhood quality measures.

\footnotetext{
${ }^{12}$ See Appendix Table A2; results are similar for aggrevated assault and motor vehicle theft, not reported in detail here.
} 
To sort out these two relationships between local crime levels and early retirement, we next explore a model that conditions on deviations from crime expectations. This is consistent with an economic framework where households make a joint plan about both residence and retirement timing when they selected their "current" home. In other words, when selecting their current home, individuals formed expectations for neighborhood amenities - including crime rates - based on actual crime patterns prior to moving into the home.

We develop an empirical approximation to this persective by estimating a linear time trend for local crime rates five years prior to when each respondent purchased his home. Thus, for example, a worker who moved into his current home in 1978 would form his expectations for future crime rates based on a projection of the actual local crime rate trend realized over the period 19731977. With an expectation for future crime rates based on this linear forecast, we then posit that when realized crime proves to be different than expectations, this deviation is regarded as a surprise to the individual and exogenous to his initial residential choice decision. More specifically, the assumption is that, controlling for the initial conditions, including expections for crime in 1992, respondents are otherwise equal save for shocks orthogonal to the initial conditions. This methodology could lead to systematic variation in deviations from expectations depending on the length of the projection, so we add to the set of initial conditions the year the respondent moved into his current home.

This linear forecasting method of predicting future crime is reasonably accurate for murder rates: among HRS sample men, the average prediction for the 1992 murder rate has a median deviation from expectations of zero, and exceeds the realized rate by 0.26 murders per 10,000 residents on average (with a standard deviation 2.43 for over 18 years on average). Predictions for women are similarly accurate with respect to the murder rate. When we turn to assault rates, instead, expectations are somewhat less accurate: for men, the median deviation is just 3.4 assaults per 
10,000 residents, whereas average assault rates exceed realized rates by 20.4 assaults per 10,000 residents (with a standard deviation of 101.13).

We allow for a possible correlation between crime levels and residential choice in Columns (2)-(4) of Tables 2-5. Note that the sample size differs somewhat from earlier results, due to missing data in the HRS on the timing of home purchase choice and the fact that most renters are not asked when they moved into their current home. For the 1,299 respondents who do give necessary information, we provide results in Table 3. In Column 2 we show that conditioning on expectations for crime in 1992, rather than the realized level in 1992 preserves the previously reported positive relationship between crime levels and early retirement. The coefficient on the expected murder rate is, as in Column (1), positive, and unlike the realized level estimate, statistically different from zero. We interpret this result from Column (2) to indicate that those who choose to live in communities with higher expected future crime rates are also more likely to choose to retire early. We do not interpret this coefficient to describe the causal effect of increased crime rates on the propensity for early retirement.

Conditioning on deviations from murder rate expectations and the timing of residence choice, in Column (3) of Table 3, permits causal inference in the context of our framework. Among HRS men, deviations from murder rate expectations have a positive, but statistically insignificant relationship with early benefit takeup, while the expected level coefficient on the murder rate remains positive. We interpret these results as evidence that decisions to reside in an area with higher expected crime are significantly and positively correlated with early retirement, and as inconclusive evidence that unexpected increases in the murder rate, on average, increase the propensity for early retirement.

The findings are qualitatively similar when we replace murder rates with assault rates as the crime measure; however, the assault estimates provide somewhat firmer evidence that, on average, 
unexpected increases in crime increase the propensity for early retirement. See Table A2 column (3). In the assault specification, the magnitude of the coefficient on the unexpected crime rate is the same as that for the expected crime rate, and the estimate is relatively more precise than that from the murder specification. Neither coefficient, is however, statistically distinguishable from zero at the $5 \%$ confidence level.

The preceding two paragraphs describe limited evidence for unanticipated increases in crime having, on average, a positive effect on the propensity for early retirement. In the introduction, however, we described how certain subgroups may, by virtue of the ir health or resources, be made particularly sensitive to unanticipated changes in crime. The results presented in Column (4) of Table 3 indicate that, indeed, unexpected increases in murder rates have different effects depending on the respondent's health Among those in fair or poor health, unanticipated increases in crime are associated with statistically significant, and economically important increases in the propensity for early retirement. For those reporting fair or poor health in 1992, the coefficient on unexpected crime increases is given by the sum of -0.030 and the interaction term coefficient 0.189 , i.e. 0.159 . Among those who report that their health is good or excellent, the coefficient on unexpected increases in crime is actually negative, -0.030 , though not nearly statistically distinguishable from zero. Consequently, older workers in fair-poor health have a statistically significant reaction to unexpected changes in murder rates, while those in better health do not change their retirement timing. There is no significant impact of household wealth interactions. ${ }^{13}$

Results are similar, though less precisely estimated, for the zero hours of work definition of early retirement. Column (3) of Table 4 conditions on both the expected level and the deviation from expected murder rate levels where we find a small, statistically insignificant negative association between early retirement and unexpectedly high local murder rates among men. Again, 
however, interactions with health suggest results qualitatively in line with those reported earlier: those in poor health are substantially more likely to take early retirement when faced with surprisingly high local crime, with little evidence of wealth impacts.

Among women, accounting for crime expectations produces qualitatively similar results, though again they are less precisely estimated. Column (3) of Table 5 focuses on early benefit receipt, and again both expected and unexpected levels of murder rates are positively with early retirement, though the point estimates are not statistically different from zero. While the level effects are not significant, so we cannot reject a null hypothesis of no effect of unexpected crime on retirement behavior, the response to unexpected changes in the crime level appears again to depend on the health, but not on the wealth of the individual. Among women in good health, there is a negative association between unexpected murder rate increases and the propensity to retire early, though this relationship is not precisely estimated. For women in poor health, as was true for men, the coefficient is positive.

\section{Discussion}

To help interpret our results, Table 6 presents summary retirement responses to changes in crime expectations for men. Using estimates from Column (4) of Tables 3, we report the predicted changes in the probability of retiring early, defined as receiving government benefits, associated with a standard deviation increase in unanticipated murder rates. These values are generated for otherwise average men in excellent-good and fair-poor health, with different levels of education. The estimates indicate that, among men in better health, unanticipated increases in local murder rates have no impact on the timing of retirement. Among men who self-report fair or poor health, however, the probability of early retirement increases by 9.4 percentage points when faced with a

\footnotetext{
${ }^{13}$ Using assault rates rather than murder rates changes the sign of the point estimate of the interaction term on health
} 
standard deviation increase in unanticipated murder rates. For this group, this change in retirement behavior represents an approximately 14 percent increase in the probability of early retirement. This predicted increase in the probability of early retirement differs slightly by education group. We find that those with only a high school degree are somewhat less sensitive to unanticipated changes in the crime rate then are those with more or less education, but these differences by education group are not statistically significant.

\section{Table 6 here}

\section{Conclusions}

This paper represents a first step towards a better understanding of the relationship between local crime and the labor supply of older Americans. Our results indicate the importance of taking account of expectations for future crime when analyzing the effect of variation in crime on labor market decisions. In our samples, while the estimated relationship between (expected) murder rates and the propensity for early retirement is positive, the relationship between unexpected changes in the murder rate and early retirement is generally indistinguishable from zero. Our results also indicate the importance of differentiating between groups with different resources and endowments. For those in poor health, we find that both expected and unexpected increases in murder rates are associated with significantly earlier retirement. Our results thus suggest that the decision to live in a higher crime area may be positively correlated with early retirement plans, while unanticipated increases in murder rates appear to delay the retirement of those in poor health only.

Further analysis will be needed to assess whether our results are robust to the inclusion of additional controls for household retirement wealth including data on pensions and Social Security taken from administrative records. We also seek to better understand why the effects of local crime may have different effects for men versus women, and why measured effects of crime on retirement 
differ depending on the specification of the dependent variable. Examination of the effects of local crime on other activities may also shed light may also be shed on the effects of crime on the labor supply of older Americans. Further work should examine the influence of crime on both volunteer work and on older peoples' residency decisions. As the HRS longitudinal survey continues, there will be additional opportunities to refine our analysis of the effects of local crime on these and other older persons' retirement outcomes. 
Table 1: National and HRS Average Crime Rates, by Type of Crime and County Size

\begin{tabular}{|l|c|c|c|c|c|c|}
\hline Crime & $\begin{array}{c}\text { National } \\
\text { Average } \\
\text { Rate }\end{array}$ & $\begin{array}{c}\text { Age-eligible } \\
\text { HRS Average } \\
\text { Rate }\end{array}$ & $\begin{array}{c}\text { Subsample of } \\
\text { HRS Average } \\
\text { Rate }\end{array}$ & $\begin{array}{c}\text { National } \\
\text { Average Rate } \\
(100 \mathrm{~K}+)\end{array}$ & $\begin{array}{c}\text { Age-eligible } \\
\text { HRS Average } \\
\text { Rate (100K +) }\end{array}$ & $\begin{array}{c}\text { Subsample of } \\
\text { HRS Average } \\
\text { Rate (100K +) }\end{array}$ \\
\hline Murder & 0.958 & 1.018 & 0.972 & 1.11 & 1.147 & 1.093 \\
& $(2954)$ & $(9839)$ & $(2355)$ & $(447)$ & $(7142)$ & $(1666)$ \\
\hline Assault & 42.08 & 39.83 & 38.44 & 47.97 & 48.12 & 47.09 \\
& $(2952)$ & $(9410)$ & $(2268)$ & $(445)$ & $(6713)$ & $(1579)$ \\
\hline Robbery & 24.48 & 23.72 & 21.98 & 31.90 & 31.61 & 29.76 \\
& $(2592)$ & $(9410)$ & $(2268)$ & $(445)$ & $(6713)$ & $(1579)$ \\
\hline Vehicle & 54.87 & 57.09 & 54.86 & 70.38 & 74.23 & 72.18 \\
theft & $(2946)$ & $(8815)$ & $(2143)$ & $(439)$ & $(6118)$ & $(1454)$ \\
\hline
\end{tabular}

Crime rates are per 10,000 residents. Sample size is in parentheses.

Source: Authors' computations; HRS data linked with FBI Uniform Crime Reports.

\begin{tabular}{|l|l|}
\hline \multicolumn{2}{|l|}{ Crime Definitions: FBI Uniform Crime Reports } \\
\hline Crime & Definition \\
\hline Murder & $\begin{array}{l}\text { The willful (nonnegligent) killing of one human by another. This definition does not include deaths } \\
\text { caused by negligence, suicide, or accident. It does not include justifiable homicides. }\end{array}$ \\
\hline Assault & $\begin{array}{l}\text { An unlawful attack, by one person upon another, for the purpose of inflicting severe or aggravated } \\
\text { bodily injury. }\end{array}$ \\
\hline Robbery & $\begin{array}{l}\text { The taking, or attempted taking, of anything of value from the care custody, or control of a person } \\
\text { or persons by force or threat of force or violence and/or by putting the victim in fear. }\end{array}$ \\
\hline Vehicle theft & The theft or attempted theft of a motor vehicle. \\
\hline
\end{tabular}

Source: FBI (1999) 


\begin{tabular}{|c|c|c|c|c|}
\hline \multirow[t]{2}{*}{ Retirement Definition } & \multicolumn{2}{|c|}{$\begin{array}{l}\text { Any Government } \\
\text { Benefits } \\
\text { (I) }{ }^{15}\end{array}$} & \multicolumn{2}{|c|}{$\begin{array}{c}\text { Move to } \\
\text { Zero Hours of work } \\
\text { (II) }\end{array}$} \\
\hline & $\begin{array}{c}\text { Early } \\
\text { Retirees }\end{array}$ & Others & $\begin{array}{c}\text { Early } \\
\text { Retirees }\end{array}$ & Others \\
\hline & $\begin{array}{c}\text { Mean/Med. } \\
(\mathrm{SE})\end{array}$ & $\begin{array}{c}\text { Mean/Med. } \\
(\mathrm{SE})\end{array}$ & $\begin{array}{c}\text { Mean/Med. } \\
(\mathrm{SE})\end{array}$ & $\begin{array}{c}\text { Mean/Med. } \\
(\mathrm{SE})\end{array}$ \\
\hline \multicolumn{5}{|l|}{ Demographics: } \\
\hline Age in 1992 & $\begin{array}{r}58.76 \\
(0.07) \\
\end{array}$ & $\begin{array}{l}58.57 \\
(0.06) \\
\end{array}$ & $\begin{array}{r}58.83 \\
(0.06) \\
\end{array}$ & $\begin{array}{r}58.47 \\
(0.07) \\
\end{array}$ \\
\hline Black (\%) & $\begin{array}{r}6.87 \\
(1.03) \\
\end{array}$ & $\begin{array}{r}5.81 \\
(0.91) \\
\end{array}$ & $\begin{array}{r}6.42 \\
(0.95) \\
\end{array}$ & $\begin{array}{r}6.19 \\
(0.98) \\
\end{array}$ \\
\hline Hispanic (\%) & $\begin{array}{r}4.17 \\
(0.81) \\
\end{array}$ & $\begin{array}{r}4.30 \\
(0.79) \\
\end{array}$ & $\begin{array}{r}4.01 \\
(0.76) \\
\end{array}$ & $\begin{array}{r}4.50 \\
(0.85) \\
\end{array}$ \\
\hline Married (\%) & $\begin{array}{l}84.45 \\
(1.47) \\
\end{array}$ & $\begin{array}{l}87.72 \\
(1.28) \\
\end{array}$ & $\begin{array}{l}85.26 \\
(1.38) \\
\end{array}$ & $\begin{array}{l}87.21 \\
(1.36) \\
\end{array}$ \\
\hline \multicolumn{5}{|l|}{ Education (\%): } \\
\hline Less than high school & $\begin{array}{c}24.89 \\
(1.76) \\
\end{array}$ & $\begin{array}{c}19.27 \\
(1.54) \\
\end{array}$ & $\begin{array}{c}26.97 * \\
(1.72) \\
\end{array}$ & $\begin{array}{l}16.27 \\
(1.51) \\
\end{array}$ \\
\hline High school & $\begin{array}{r}34.27 \\
(1.93) \\
\end{array}$ & $\begin{array}{l}31.23 \\
(1.81) \\
\end{array}$ & $\begin{array}{l}33.81 \\
(1.84) \\
\end{array}$ & $\begin{array}{l}31.37 \\
(1.89) \\
\end{array}$ \\
\hline More than high school & $\begin{array}{l}40.83^{*} \\
(2.00) \\
\end{array}$ & $\begin{array}{l}49.37 \\
(1.95) \\
\end{array}$ & $\begin{array}{c}39.09 * \\
(1.90)\end{array}$ & $\begin{array}{l}52.36 \\
(2.04) \\
\end{array}$ \\
\hline Health (\%): & & & & \\
\hline $\begin{array}{l}\text { Self-report health } \\
\text { fair/poor }\end{array}$ & $\begin{array}{r}11.75 \\
(1.31) \\
\end{array}$ & $\begin{array}{r}9.66 \\
(1.15) \\
\end{array}$ & $\begin{array}{l}11.91 \\
(1.26) \\
\end{array}$ & $\begin{array}{r}9.23 \\
(1.18)\end{array}$ \\
\hline $\begin{array}{l}\text { Household } \\
\text { Wealth/Income: }\end{array}$ & & & & \\
\hline $\begin{array}{l}\text { R's earnings } \\
(1000 \mathrm{~s})^{* *}\end{array}$ & $\begin{array}{l}25.00 \\
(1.02) \\
\end{array}$ & $\begin{array}{l}26.20 \\
(0.92) \\
\end{array}$ & $\begin{array}{l}26.00 \\
(2.03)\end{array}$ & $\begin{array}{r}25.00 \\
(1.01)\end{array}$ \\
\hline $\begin{array}{l}\text { Household income } \\
(1000 s)^{* *}\end{array}$ & $\begin{array}{l}48.97 \\
(1.03) \\
\end{array}$ & $\begin{array}{l}53.20 \\
(1.19) \\
\end{array}$ & $\begin{array}{l}49.50 \\
(1.27)\end{array}$ & $\begin{array}{l}51.78 \\
(1.65)\end{array}$ \\
\hline $\begin{array}{l}\text { Net housing wealth } \\
\text { '92 self-report } \\
(1000 \text { s)** }\end{array}$ & $\begin{array}{l}50.00 \\
(2.55)\end{array}$ & $\begin{array}{l}52.00 \\
(2.88)\end{array}$ & $\begin{array}{l}52.75 \\
(1.65)\end{array}$ & $\begin{array}{l}51.25 \\
(1.65)\end{array}$ \\
\hline
\end{tabular}

\footnotetext{
${ }^{14}$ Smallest subsample includes only HRS age eligible respondents who were employed in 1992, remained in the study for all five of its existing waves, were at least age 65 at the time of interview in 2000, and for whom there exists crime data. Where appropriate, results are weighted using 1992 sample weights. Sample sizes vary slightly with respect to the availability of local crime measures. Murder rates are best reported; motor vehicle theft rates are least well reported. ${ }^{15}$ The definition of early retiree differs across columns I and II. Definition (I): respondent received OA, SSI, or SSDI benefits prior to age 65. Definition (II): respondent worked zero hours after 1992 and did not return to work.
} 


\begin{tabular}{|c|c|c|c|c|}
\hline $\begin{array}{l}\text { Net financial wealth } \\
\text { ' } 92 \text { self-report } \\
(1000 \text { s })^{* *}\end{array}$ & $\begin{array}{l}69.75 \\
(7.66)\end{array}$ & $\begin{array}{l}75.50 \\
(6.19)\end{array}$ & $\begin{array}{l}68.70 \\
(6.20)\end{array}$ & $\begin{array}{l}80.63 \\
(6.92)\end{array}$ \\
\hline $\begin{array}{l}\text { Community } \\
\text { Characteristics: }\end{array}$ & & & & \\
\hline Murder rate per $10 \mathrm{~K}$ & $\begin{array}{r}0.97 \\
(0.04)\end{array}$ & $\begin{array}{r}0.92 \\
(0.04)\end{array}$ & $\begin{array}{r}0.94 \\
(0.04) \\
\end{array}$ & $\begin{array}{r}0.95 \\
(0.04) \\
\end{array}$ \\
\hline Assault rate per $10 \mathrm{~K}$ & $\begin{array}{l}46.83 \\
(1.55)\end{array}$ & $\begin{array}{l}43.57 \\
(1.44)\end{array}$ & $\begin{array}{r}45.04 \\
(1.41)\end{array}$ & $\begin{array}{r}45.00 \\
(1.59)\end{array}$ \\
\hline $\begin{array}{l}\text { Neighborhood quality, } \\
\text { self-report }(0-5)^{16}\end{array}$ & $\begin{array}{l}1.20^{*} \\
(0.04) \\
\end{array}$ & $\begin{array}{r}1.05 \\
(0.03) \\
\end{array}$ & $\begin{array}{c}1.17 \\
(0.04)\end{array}$ & $\begin{array}{r}1.07 \\
(0.28) \\
\end{array}$ \\
\hline $\begin{array}{l}\text { Median housing price } \\
(1000 \mathrm{~s})\end{array}$ & $\begin{array}{l}87.75^{*} \\
(2.44)\end{array}$ & $\begin{array}{l}104.25 \\
(2.95) \\
\end{array}$ & $\begin{array}{l}97.27 \\
(2.61)\end{array}$ & $\begin{array}{l}95.60 \\
(2.92) \\
\end{array}$ \\
\hline $\mathrm{N}$ & 606 & 659 & 663 & 602 \\
\hline
\end{tabular}

Standard errors in parentheses.

* Indicates means are statistically different at least at the 5\% confidence level.

**Median earnings are reported.

\footnotetext{
${ }^{16}$ The neighborhood quality measure is an index summarizing the dichotomous responses to five questions concerning the respondent's neighborhood and his or her relationships with neighbors.
} 


\begin{tabular}{|c|c|c|c|c|}
\hline Covariates $^{1}$ & $\begin{array}{l}\text { Basic } \\
\text { Model } \\
\text { (1) }\end{array}$ & $\begin{array}{l}\text { Replacing } \\
\text { Murder rate } \\
\text { with Exp. } \\
\text { Murder rate } \\
\text { (2) }\end{array}$ & $\begin{array}{c}\text { Adding } \\
\text { Crime } \\
\text { Deviations } \\
\text { to Column } 2 \\
(3)\end{array}$ & $\begin{array}{c}\text { Adding } \\
\text { Interaction } \\
\text { Terms to } \\
\text { Column } 3 \\
(4) \\
\end{array}$ \\
\hline Murder rate '92 & $\begin{array}{l}0.085 \\
(0.066)\end{array}$ & & & \\
\hline $\begin{array}{l}\text { Expected murder } \\
\text { rate in } 1992\end{array}$ & & $\begin{array}{l}0.117 * \\
(0.040)\end{array}$ & $\begin{array}{c}0.153 * * \\
(0.088)\end{array}$ & $\begin{array}{l}0.164 * * \\
(0.090)\end{array}$ \\
\hline $\begin{array}{l}\text { Dev from expected } \\
\text { ' } 92 \text { murder rate }\end{array}$ & & & $\begin{array}{l}0.041 \\
(0.089)\end{array}$ & $\begin{array}{l}-0.030 \\
(0.098)\end{array}$ \\
\hline $\begin{array}{l}\text { Crime/Health Fair- } \\
\text { Poor Interaction }\end{array}$ & & & & $\begin{array}{l}0.189 * \\
(0.080)\end{array}$ \\
\hline $\begin{array}{l}\text { Crime/Wealth } \\
\text { Interaction Term }\end{array}$ & & & & $\begin{array}{l}0.00009 \\
(0.0002)\end{array}$ \\
\hline $\begin{array}{l}\text { Median housing } \\
\text { price }(1000 \mathrm{~s})\end{array}$ & $\begin{array}{l}-0.003 * \\
(0.001)\end{array}$ & $\begin{array}{l}-0.004 * \\
(0.001)\end{array}$ & $\begin{array}{l}-0.004 * \\
(0.001)\end{array}$ & $\begin{array}{l}-0.004 * \\
(0.001)\end{array}$ \\
\hline $\begin{array}{l}\text { Neighborhood } \\
\text { quality (self rep.) }\end{array}$ & $\begin{array}{l}0.173 * * \\
(0.099)\end{array}$ & $\begin{array}{l}0.270 * \\
(0.145)\end{array}$ & $\begin{array}{c}0.274 * * \\
(0.146)\end{array}$ & $\begin{array}{c}0.276 * * \\
(0.147)\end{array}$ \\
\hline Year of Move-In & & $\begin{array}{l}0.012 \\
(0.010)\end{array}$ & $\begin{array}{l}0.013 \\
(0.010)\end{array}$ & $\begin{array}{l}0.014 \\
(0.010)\end{array}$ \\
\hline $\mathrm{N}$ & 1166 & 664 & 664 & 664 \\
\hline Log Likelihood & -789.44 & -436.03 & -435.92 & -433.09 \\
\hline Pseudo $\mathrm{R}^{2}$ & 0.023 & 0.047 & 0.048 & 0.054 \\
\hline Chi Square Stat. & 36.66 & 43.36 & 43.58 & 49.25 \\
\hline
\end{tabular}

Standard errors are in parentheses.

${ }^{1}$ Covariates also include controls for age, race, marital status, years of completed schooling, self-reported health, income, housing and financial wealth, and a constant term, results not reported.

* Indicates coefficient is statistically different at least at the 5\% confidence level.

** Indicates coefficient is statistically different at least at the $10 \%$ confidence level. 


\begin{tabular}{|l|c|c|c|c|}
\hline \multicolumn{4}{|l|}{ Table 4: Logit Estimates of Men's Early Retirement Patterns with } \\
Respect to Murder Rates (Dependent Variable: Zero Hours of Work)
\end{tabular}

Standard errors are in parentheses.

${ }^{1}$ Covariates also include controls for age, race, marital status, years of completed schooling, self-reported health, income, housing and financial wealth, and a constant term, results not reported.

* Indicates coefficient is statistically different at least at the 5\% confidence level.

** Indicates coefficient is statistically different at least at the $10 \%$ confidence level. 


\begin{tabular}{|c|c|c|c|c|}
\hline \multicolumn{5}{|c|}{$\begin{array}{l}\text { Table 5: Logit Estimates of Women's Early Retirement Patterns with } \\
\text { Respect to Murder Rates (Dependent Variable: Any Government } \\
\text { Benefits) }\end{array}$} \\
\hline Covariates $^{1}$ & $\begin{array}{c}\text { Basic } \\
\text { Model } \\
\\
(1) \\
\end{array}$ & $\begin{array}{c}\text { Replacing } \\
\text { Murder rate } \\
\text { with Exp. } \\
\text { Murder rate } \\
\text { (2) }\end{array}$ & $\begin{array}{c}\text { Adding } \\
\text { Crime } \\
\text { Deviations } \\
\text { to Column } 2 \\
\quad(3) \\
\end{array}$ & $\begin{array}{c}\text { Adding } \\
\text { Interaction } \\
\text { Terms to } \\
\text { Column } 3 \\
\text { (4) }\end{array}$ \\
\hline Murder rate '92 & $\begin{array}{r}0.002 \\
(0.067)\end{array}$ & & & \\
\hline $\begin{array}{l}\text { Expected murder } \\
\text { rate in } 1992\end{array}$ & & $\begin{array}{r}0.032 \\
(0.033)\end{array}$ & $\begin{array}{l}0.041 \\
(0.092)\end{array}$ & $\begin{array}{r}0.032 \\
(0.092)\end{array}$ \\
\hline $\begin{array}{l}\text { Dev from } \\
\text { expected '92 }\end{array}$ & & & $\begin{array}{r}0.010 \\
(0.092)\end{array}$ & $\begin{array}{l}-0.026 \\
(0.098)\end{array}$ \\
\hline $\begin{array}{l}\text { Crime/Health } \\
\text { Fair-poor }\end{array}$ & & & & $\begin{array}{l}0.110 \\
(0.100)\end{array}$ \\
\hline $\begin{array}{l}\text { Crime/Wealth } \\
\text { Interaction Term }\end{array}$ & & & & $\begin{array}{l}0.00009 \\
(0.00015)\end{array}$ \\
\hline $\begin{array}{l}\text { Median housing } \\
\text { price (1000s) }\end{array}$ & $\begin{array}{l}-0.001 \\
(0.001)\end{array}$ & $\begin{array}{l}-0.002 \\
(0.001)\end{array}$ & $\begin{array}{l}-0.002 \\
(0.001)\end{array}$ & $\begin{array}{l}-0.002 \\
(0.001)\end{array}$ \\
\hline $\begin{array}{l}\text { Neighborhood } \\
\text { quality (self rep.) }\end{array}$ & $\begin{array}{l}-0.006 \\
(0.046)\end{array}$ & $\begin{array}{l}-0.020 \\
(0.065)\end{array}$ & $\begin{array}{l}-0.020 \\
(0.065)\end{array}$ & $\begin{array}{l}-0.013 \\
(0.065)\end{array}$ \\
\hline Year of Move-In & & $\begin{array}{c}0.013 \\
(0.010)\end{array}$ & $\begin{array}{c}0.013 \\
(0.010)\end{array}$ & $\begin{array}{c}0.013 \\
(0.010)\end{array}$ \\
\hline $\mathrm{N}$ & 1091 & 635 & 635 & 635 \\
\hline Log Likelihood & -745.91 & -426.39 & -426.39 & -425.70 \\
\hline Pseudo $\mathrm{R}^{2}$ & 0.010 & 0.026 & 0.026 & 0.028 \\
\hline Chi Square Stat. & 14.91 & 23.08 & 23.09 & 24.46 \\
\hline
\end{tabular}

Standard errors are in parentheses.

${ }^{1}$ Covariates also include controls for age, race, marital status, years of completed schooling, self-reported health, income, housing and financial wealth, and a constant term, results not reported.

* Indicates coefficient is statistically different at least at the 5\% confidence level.

** Indicates coefficient is statistically different at least at the $10 \%$ confidence level. 
Table 6: Impact of Unexpected Increases in Murder Rates on Probability of Early Retirement, Government Benefits Definition, Men in the HRS

\begin{tabular}{|c|c|c|c|}
\hline & \multicolumn{3}{|c|}{$\begin{array}{c}\text { Change in Predicted Probability of Early Retirement from } \\
\text { Standard Deviation Increase in Unexpected in Crime Rate }\end{array}$} \\
\hline Self Reported Health & $\begin{array}{c}\text { Less than 12 Years } \\
\text { of Schooling }\end{array}$ & $\begin{array}{c}\text { 12 Years of } \\
\text { Schooling }\end{array}$ & $\begin{array}{c}\text { More than 12 Years } \\
\text { of Schooling }\end{array}$ \\
\hline Good/Excellent & -0.017 & -0.018 & -0.017 \\
\hline Fair/Poor & 0.094 & 0.082 & 0.094 \\
\hline
\end{tabular}




\begin{tabular}{|c|c|c|}
\hline & $\begin{array}{l}\text { Males and } \\
\text { Females }\end{array}$ & $\begin{array}{l}\text { Males } \\
\text { Only }\end{array}$ \\
\hline Murder rate '92 & $\begin{array}{l}-0.021 \\
(0.027) \\
\end{array}$ & $\begin{array}{l}-0.028 \\
(0.037) \\
\end{array}$ \\
\hline Age in 1992 & $\begin{array}{l}0.156^{*} \\
(0.005) \\
\end{array}$ & $\begin{array}{l}0.066^{*} \\
(0.006) \\
\end{array}$ \\
\hline Male & $\begin{array}{c}-0.274 * \\
(0.055)\end{array}$ & \\
\hline Black & $\begin{array}{c}-0.192 * \\
(0.077)\end{array}$ & $\begin{array}{c}-0.253 * \\
(0.110)\end{array}$ \\
\hline Hispanic & $\begin{array}{c}-0.457^{*} \\
(0.107) \\
\end{array}$ & $\begin{array}{c}-0.335^{*} \\
(0.136) \\
\end{array}$ \\
\hline Married & $\begin{array}{c}-0.401^{*} \\
(0.062)\end{array}$ & $\begin{array}{l}-0.010 \\
(0.099) \\
\end{array}$ \\
\hline High school & $\begin{array}{l}0.180 * \\
(0.068) \\
\end{array}$ & $\begin{array}{c}0.156 \\
(0.091) \\
\end{array}$ \\
\hline More than high school & $\begin{array}{l}0.184 * \\
(0.070) \\
\end{array}$ & $\begin{array}{l}0.068 \\
(0.092) \\
\end{array}$ \\
\hline Self-report health fair/poor & $\begin{array}{c}-0.929 * \\
(0.075) \\
\end{array}$ & $\begin{array}{c}-0.901 * \\
(0.102) \\
\end{array}$ \\
\hline R's earnings (1000s) & $\begin{array}{l}0.016 * \\
(0.001) \\
\end{array}$ & $\begin{array}{l}0.007 * \\
(0.001) \\
\end{array}$ \\
\hline Household income (1000s) & $\begin{array}{l}-0.0005 \\
(0.0007) \\
\end{array}$ & $\begin{array}{c}0.0003 \\
(0.0009) \\
\end{array}$ \\
\hline $\begin{array}{l}\text { Net housing wealth self report } \\
(1000 \mathrm{~s})\end{array}$ & $\begin{array}{c}-0.0007^{*} \\
(0.0003)\end{array}$ & $\begin{array}{l}-0.0005 \\
(0.0004) \\
\end{array}$ \\
\hline $\begin{array}{l}\text { Net financial wealth self report } \\
(1000 \text { s) }\end{array}$ & $\begin{array}{l}0.00001 \\
(0.00006) \\
\end{array}$ & $\begin{array}{l}0.00005 \\
(0.00007) \\
\end{array}$ \\
\hline Constant & $\begin{array}{l}-9.994 * \\
(0.319) \\
\end{array}$ & $\begin{array}{c}-5.099 * \\
(0.390) \\
\end{array}$ \\
\hline $\mathrm{N}$ & 12522 & 5853 \\
\hline Log Likelihood & -5341.68 & -2890.71 \\
\hline Pseudo $\mathrm{R}^{2}$ & 0.115 & 0.046 \\
\hline Chi Squared Test & 1393.88 & 276.76 \\
\hline
\end{tabular}

Standard errors in parentheses. *Statistically significant at the $5 \%$ level.

\footnotetext{
${ }^{17}$ Sample includes all age eligible HRS respondents. Dependent variable is an indicator for inclusion in the primary HRS subsample used in our analysis
} 


\begin{tabular}{|c|c|c|c|c|}
\hline \multicolumn{5}{|c|}{$\begin{array}{l}\text { Table A2: Logit Estimates of Men's Early Retirement Patterns with } \\
\text { Respect to Assault Rates (Dependent Variable: Any Government Benefits) }\end{array}$} \\
\hline Covariates $^{1}$ & $\begin{array}{l}\text { Basic } \\
\text { Model } \\
\\
\text { (1) }\end{array}$ & $\begin{array}{c}\text { Replacing } \\
\text { Assault rate } \\
\text { with Exp. } \\
\text { Assault rate } \\
\text { (2) }\end{array}$ & $\begin{array}{c}\text { Adding } \\
\text { Crime } \\
\text { Deviations } \\
\text { to Column } 2 \\
(3)\end{array}$ & $\begin{array}{c}\text { Adding } \\
\text { Interaction } \\
\text { Terms to } \\
\text { Column } 3 \\
\text { (4) }\end{array}$ \\
\hline Assault rate ' 92 & $\begin{array}{c}0.004 * * \\
(0.002)\end{array}$ & & & \\
\hline $\begin{array}{l}\text { Expected assault } \\
\text { rate in } 1992\end{array}$ & & $\begin{array}{c}0.001 \\
(0.0008)\end{array}$ & $\begin{array}{l}0.004 * * \\
(0.0027)\end{array}$ & $\begin{array}{c}0.004 \\
(0.0027)\end{array}$ \\
\hline $\begin{array}{l}\text { Dev from } \\
\text { expected '92 }\end{array}$ & & & $\begin{array}{l}0.0035 \\
(0.0028)\end{array}$ & $\begin{array}{l}0.0043 \\
(0.0029)\end{array}$ \\
\hline $\begin{array}{l}\text { Crime/Health } \\
\text { Fair-poor }\end{array}$ & & & & $\begin{array}{l}-0.0026 \\
(0.003)\end{array}$ \\
\hline $\begin{array}{l}\text { Crime/Wealth } \\
\text { Interaction Term }\end{array}$ & & & & $\begin{array}{c}-4.35 e-6 \\
2.84 e-6\end{array}$ \\
\hline $\begin{array}{l}\text { Median housing } \\
\text { price (1000s) }\end{array}$ & $\begin{array}{l}-0.004 * \\
(0.001)\end{array}$ & $\begin{array}{l}-0.004 * \\
(0.001)\end{array}$ & $\begin{array}{l}-0.004 * \\
(0.001)\end{array}$ & $\begin{array}{l}-0.004 * \\
(0.001)\end{array}$ \\
\hline $\begin{array}{l}\text { Neighborhood } \\
\text { quality (self rep.) }\end{array}$ & $\begin{array}{l}0.181 \\
(0.120)\end{array}$ & $\begin{array}{c}0.257 * * \\
(0.144)\end{array}$ & $\begin{array}{c}0.275 * * \\
(0.145)\end{array}$ & $\begin{array}{c}0.273 * * \\
(0.145)\end{array}$ \\
\hline Year of Move-In & & $\begin{array}{l}0.006 \\
(0.010)\end{array}$ & $\begin{array}{l}0.008 \\
(0.010)\end{array}$ & $\begin{array}{l}0.007 \\
(0.010)\end{array}$ \\
\hline $\mathrm{N}$ & 784 & 662 & 662 & 662 \\
\hline Log Likelihood & -521.20 & -437.75 & -436.97 & -435.16 \\
\hline Pseudo $\mathrm{R}^{2}$ & 0.037 & 0.040 & 0.041 & 0.045 \\
\hline Chi Square Stat. & 39.86 & 36.02 & 37.59 & 41.21 \\
\hline
\end{tabular}

Standard errors are in parentheses.

${ }^{1}$ Covariates also include controls for age, race, marital status, years of completed schooling, self-reported health, income, housing and financial wealth, and a constant term, results not reported.

* Indicates coefficient is statistically different at least at the 5\% confidence level.

** Indicates coefficient is statistically different at least at the $10 \%$ confidence level. 


\section{References:}

Anderson, Elijah (1990), Streetwise: Race, Class, and Change in an Urban Community, Chicago: University of Chicago Press.

(1999), Code of the Street: Decency, Violence, and the Moral Life of the Inner City, New York: W.W. Norton.

Becker, Gary S. (1968), "Crime and Punishment: An Economic Approach", Journal of Political Economy, 76 (2): 169-217.

Brillon, Yves (1987), Victimization and Fear of Crime Among the Elderly, Toronto: Butterworths.

Cullen, Julie B. and Steven D. Levitt (1999), "Crime, Urban Flight, and the Consequences for Cities," The Review of Economics and Statistics, 81(2): 159-169.

Dwyer, Deborah and Olivia S. Mitchell (1998), "Physical Health, Mental Health and Retirement in the Health and Retirement Survey", Journal of Health Economics, 18 (2): 173-193.

Federal Bureau of Investigation (1999). Crime in the United States: Uniform Crime Reports. Washington D.C.: U.S. Government Printing Office: ISBN 0-16-048756-0.

Fields, Gary S. and Olivia S. Mitchell. Retirement, Pensions and Social Security. Cambridge, MA: MIT Press, 1983.

Glaeser, Edward L., Bruce Sacerdote, and José Scheinkman (1996). “Crime and Social Interactions.” Quarterly Journal of Economics. 111(2): 507-548.

Grogger, Jeff (1998), "Market Wages and Youth Crime", Journal of Labor Economics, 16 (4): 75691.

Gruber, Jonathan and David A. Wise (1999), "Social Security Programs and Retirement Around the World", in J. Gruber and D. A. Wise eds. Social Security Around the World, Chicago: University of Chicago Press.

Gustman, Alan L., Olivia S. Mitchell, Andrew A. Samwick, and Thomas L. Steinmeier. "Evaluating Pension Entitlements." In Forecasting Retirement Needs and Retirement Wealth. Eds. O.S. Mitchell, B. Hammond, and A. Rappaport. Pension Research Council. Philadelphia, PA: University of Pennsylvania Press, 2000: 309-326.

Hamermesh, Daniel S. (1999), "Crime and the Timing of Work", Journal of Urban Economics, 45 (2):311:330.

Levitt, Steven D. (1997), "Using Electoral Cycles in Police Hiring to Estimate the Effect of Police on Crime." American Economic Review. 87(3):270-290.

(1998), "Juvenile Crime and Punishment," Journal of Political Economy, 106 (6): 1156-85.

Lumsdaine, Robin L. and Olivia S. Mitchell (1999), "New Developments in the Economic Analysis of Retirement," in O. Ashenfelter and D. Card, eds. Handbook of Labor Economics, Elsevier Science.

Mitchell, Olivia S., Jan Olson and Thomas Steinmeier (2000). "Earnings and Projected Benefits." In Forecasting Retirement Needs and Retirement Wealth. Eds. O.S. Mitchell, B. Hammond, and A. Rappaport. Pension Research Council. Philadelphia, PA: University of Pennsylvania Press:6894. 
Philadelphia Police Department (1999). "Patrol District Crime Statistics -- 1999." URL: http://www.ppdonline.org/ppd_statdist99.htm.

Rennison, Callie M. (1999), "Criminal Victimization 1998: Changes 1997-98 with Trends 199398," Bureau of Justice Statistics National Crime Victimization Survey, U.S. Department of Justice, NCJ 176353.

Rust, John and Christopher Phelan (1997), "How Social Security and Medicare Affect Retirement Behavior in a World of Incomplete Markets," Econometrica, 65 (4): 781-831.

Sampson, Robert J. and John D. Wooldredge, (1986) "Evidence that High Crime Rates Encourage Migration Away from Central Cities," Sociology and Social Research, 70 (4): 310-314.

Stock, James H. and David A Wise (1990), "Pensions, the Option Value of Work and Retirement," Econometrica, 58 (5): 1151-1180. 